\title{
The Antigenic Structure of Haemophilus and Coryne- bacterium Species from the Human Genital Tract Claimed to be Associated with or Derived from Mycoplasma hominis
}

\author{
By PHYLLIS PEASE and NANCY LAUGHTON \\ Department of Virology and Bacteriology, University of Birmingham
}

(Received 28 December 1964)

\section{SUMMARY}

The antigenic structure of Haemophilus vaginalis (Gardner \& Dukes, Edmunds, and Amies \& Jones strains) was compared by means of geldiffusion precipitin reactions with that of $H$. influenzae and Corynebacterium cervicis (Laughton). Haemophilus vaginalis (Amies \& Jones) was closely related to $H$. influenzae, and formed a group with related species; H. vaginalis (Gardner \& Dukes) and C. cervicis formed separate groups; but all three groups possessed common antigenic components.

These strains of bacteria are among those reported as being related to Mycoplasma hominis, and their antigenic relationships are thus of importance in this connexion.

\section{INTRODUCTION}

Several observations have been published tending to establish a relationship between Mycoplasma hominis and certain bacteria which have been described as species of the genus Corynebacterium (Minck, 1953; Wittler, Cary \& Lindberg, 1956; Smith, Peoples \& Morton, 1957; Pease \& Laughton, 1962; Pease, 1962) or of the genus Haemophilus (Amies \& Jones, 1957). Whereas in most of these cases the mycoplasma (PPLO) concerned have been identified as $M$. hominis type 1 or type 2 (Campo), the identity of the related bacteria has been problematical. One of these, described by Pease \& Laughton (1962), was identical with Corynebacterium cervicis (Laughton, 1951, 1954). Amies \& Jones (1957) identified their organism as Haemophilus vaginalis, but Lapage (1961) and Zinnemann \& Turner (1963) considered that it was identical with $H$. influenzae, and this was supported by the serological studies of Redmond \& Kotcher (1963). Pease \& Laughton (1962) noted resemblances between the descriptions of $\boldsymbol{H}$. vaginalis (Leopold, 1953, 1956; Gardner \& Dukes, 1955; Edmunds, 1960, 1962; Lapage, 1961) and C. cervicis.

In the present study we have examined, by the gel diffusion technique, the antigenic relationships of Corynebacterium cervicis, Haemophilus vaginalis (Amies \& Jones), $\boldsymbol{H}$. vaginalis (Edmunds) and $\boldsymbol{H}$. vaginalis (Gardner \& Dukes), with the object of obtaining information upon the bacterial types claimed to be related to Mycoplasma hominis. 


\section{METHODS}

Organisms. Seven strains of Corynebacterium cervicis (Laughton: $12 \mathrm{EA}, 9 \mathrm{~T}, \mathrm{~A} 9 \mathrm{~T}$, $16 \mathrm{~T}, 18 \mathrm{~T}, 25 \mathrm{~T}, 26 \mathrm{~T}$ ) had been isolated in this laboratory from human genital tracts; one strain of Haemophilus vaginalis (Gardner \& Dukes: G-D) and two of $\boldsymbol{H}$. vaginalis (Amies \& Jones: H 689, Dingham) were provided by Dr K. Zinnemann; seven strains of $H$. vaginalis (Edmunds: GPI to GP7 inclusive) were provided by Dr P.N. Edmunds. For comparison, five strains of $\boldsymbol{H}$. influenzae (originally Pitman types $a, c, d, e, f$; capsules were not investigated), and one of $H$. parainfluenzae were obtained from the National Collection of Type Cultures.

Serology. Antigens were prepared in the same manner for rabbit immunization and for gel-diffusion tests. The bacteria were grown for $48 \mathrm{hr}$ at $37^{\circ}$ in Fildes digest broth or in the medium described by Laughton (1963); they were harvested by centrifugation and washed three times with physiological saline containing $0.5 \%(\mathrm{w} / \mathrm{v})$ phenol, made up to a concentration corresponding to 3 times that of no. 9 Brown's opacity tube (Burroughs Wellcome), centrifuged, subjected to ultrasonic disintegration for periods up to $20 \mathrm{~min}$. according to the degree of resistance shown, and restored, in the same solution, to the volume at which opacity was measured. Rabbits were immunized, first by two subcutaneous injections at an interval of 14 days (each $1 \mathrm{ml}$. antigen $+1 \mathrm{ml}$. Freund's adjuvant) followed by a graded series of intravenous injections of the antigen alone (0.5-2 ml.) increasing by $0.5 \mathrm{ml}$. on ten occasions over 3 weeks. After a further 10-14 days the animals were bled and re-immunized when necessary.

The gel-diffusion agar had the following composition: sodium barbitol, 7.0 g.; sodium chloride, $6.0 \mathrm{~g}$; $\mathrm{N}-\mathrm{HCl}, 2.7 \mathrm{ml}$; Davis agar, $12.0 \mathrm{~g}$.; distilled water to $1 \mathrm{l}$; adjusted to $\mathrm{pH} 7 \cdot 4$.

Gel-diffusion tests were made at $20^{\circ}$ in a moist atmosphere and readings were taken at intervals up to 10 days.

The following controls were used. Because the media used for growth contained horse serum, an excess of it $(\mathbf{2 5} \%)$ was included in the agar gel to eliminate false reactions from this source. Control antigens, comprising the complete media and also, separately, laked horse red cells and Fildes digest broth, were included in each set of tests, at the usual concentrations and in $1 / 2,1 / 4,1 / 8,1 / 16,1 / 32$ dilutions. Whole bacteria were also tested as control antigens to eliminate the possibility of false positive reactions arising from soluble matter included in the suspensions. Preimmunization sera were included in the tests, providing a control against nonspecific antibodies and (these being negative) also against false positive reactions to constituents of the gel, by either antigens or sera. Agar was not used in the preparation of the antigens.

\section{RESULTS}

Sera were prepared against Haemophilus vaginalis (Edmunds) strains GP 1, GP 2, GP 3, GP 6, GP 7; H. vaginalis (Gardner \& Dukes) G-D; $H$. vaginalis (Amies \& Jones) н 689 and Dingham; Corynebacterium cervicis strains $12 \mathrm{EA}, 9 \mathrm{~T}, 26 \mathrm{~T}$. These 11 sera were tested against all 21 strains of bacteria listed in the previous section. The results are shown in Table 1 . The vertical lines represent the number of distinguishable lines in each positive precipitin reaction. It appears that on this basis the 
organisms formed three groups: one containing the Haemophilus vaginalis strains Edmunds and Gardner \& Dukes; the second, the Haemophilus species of Amies \& Jones and the NCTC strains; the third, Corynebacterium cervicis. A degree of crossrelationship existed between some members of different groups.

Table 1. Gel-diffusion precipitin reactions

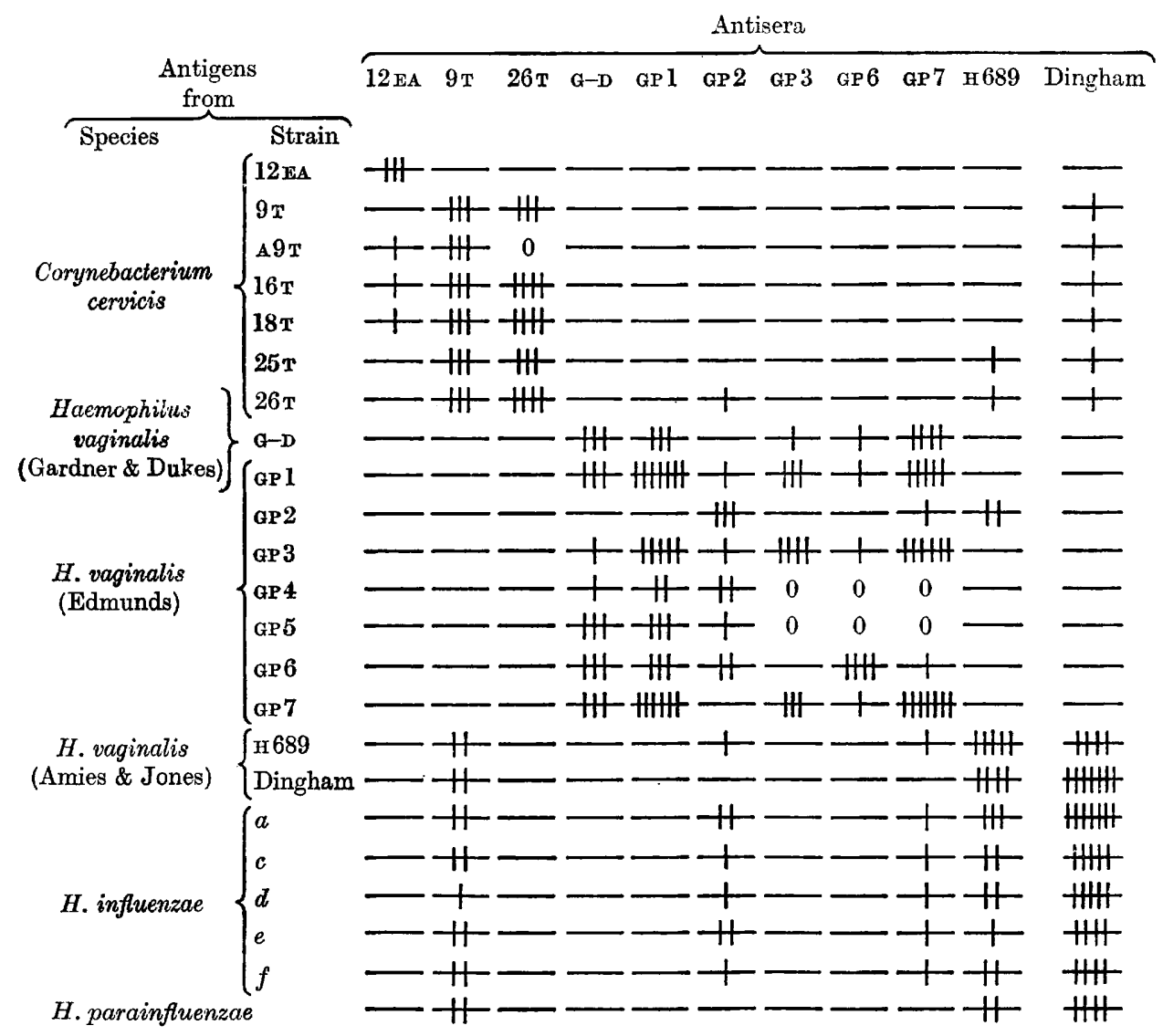

- negative; \#, vertical strokes represent number of visible lines of precipitation; 0 , not performed.

To identify further the antigens responsible for these positive reactions, each serum was tested simultaneously against all the strains with which it reacted. The antigens were placed in cups either around the circumference of the cup containing the serum, or parallel with a trough of serum. In this way the identity or otherwise of lines of precipitation could be determined. These analyses were repeated with different batches of antigens, prepared on at least three different occasions in each case. This was done because the strength of individual lines varied from preparation to preparation of antigen, both relatively and absolutely, probably because of the hazards of preparation by ultrasonic disintegration and possibly also because of antigenic variation. Some of the antigenic components represented in the sera 
reacted more strongly with related than with homologous antigens. This phenomenon became more important when PPLO antigens were examined (see Pease, 1965).

The results of these analyses are given in Table 2. The antigens are numbered in arabic numerals, and their position in the series has no significance. Factors appearing most strongly as antibodies in the homologous bacteria are shown in parentheses.

\section{Table 2. Antigenic structure of some Haemophilus and Corynebacterium organisms}

Antigens are numbered arbitrarily. Those shown in parentheses were regularly demonstrable in sera but only in concentrated antigenic preparations.

\begin{tabular}{|c|c|}
\hline Specific groups & Antigens \\
\hline $\begin{array}{l}\text { Haemophilus vaginalis } \\
\text { (a) Edmunds strains } \\
\text { (b) Gardner \& Dukes strains }\end{array}$ & $\begin{array}{l}1,2,3,4,5,6,7,8,9,10,(11),(17) \\
(1), 2,3,8,9,(10)\end{array}$ \\
\hline $\begin{array}{l}\text { H. influenzae } \\
\text { (a) Respiratory strains } \\
\text { (b) Amies \& Jones strains }\end{array}$ & $\begin{array}{l}17,18,32,38,34,35,36,38 \\
11,17,18,31,32,33,34,35,36,37,38\end{array}$ \\
\hline Corynebacterium cervicis strains & $11,15,16,17,18,19,20,21,22,28,24$ \\
\hline
\end{tabular}

\section{DISCUSSION}

There are numerous suggestions in the literature of a relationship between the genera Haemophilus and Corynebacterium. Deacon, Albritton, Edmundson \& Olansky (1954) and McKay \& Truscott (1959) described Gram-positive corynebacterium-like variants of $\boldsymbol{H}$. ducreyi and $\boldsymbol{H}$. gallinarum, respectively. The organism described as $H$. vaginalis by Gardner \& Dukes (1955) and by Edmunds $(1960,1962)$ was considered by Lapage (1961) to resemble a corynebacterium, and was renamed C. vaginale by Zinnemann \& Turner $(1962,1963)$. Pease \& Bisset (1962) suggested that the genus Haemophilus was a Gram-negative derivative of the genus Corynebacterium.

The results of the present investigation confirm that the Haemophilus vaginalis of Amies \& Jones (1957) is serologically very close to $H$. influenzae, and that both species have antigens in common with the corynebacterium-like $\boldsymbol{H}$. vaginalis of Gardner \& Dukes, and with $C$. cervicis (Laughton), both of which vary between a Gram-positive and a Gram-negative phase. The relationship between these genera, which have been especially closely associated with PPLO, is of great interest in the solution of the problem of the origin and relationships of PPLO. The antigens defined in the present work also appear to be of significance to the problem of the antigenic structure of PPLO and their presumed parent bacteria (Pease, 1965).

\section{REFERENCES}

Amies, C. R. \& Jones, S. A. (1957). A description of Haemophilus vaginalis and its Lforms. Can. J. Microbiol. 3, 579.

Deacon, W. E., Ambrituon, D. C., Edmundson, W. F. \& Olansky, S. (1954). Study of Ducrey's bacillus and recognition of a Gram-positive smooth phase. Proc. Soc. exp. Biol. Med. 86, 261.

Edmunds, P. N. (1960). Haemophilus vaginalis: morphology, cultural characters and viability. J. Path. Bact. 79, 278. 
Edmunds, P. N. (1962). The biochemical, serological and haemagglutinating reactions of Haemophilus vaginalis. J. Path. Bact. 83, 411.

Gardner, H. L. \& Dukes, C. D. (1955). Haemophilus vaginalis; newly defined specific infection previously classified 'nonspecific' vaginitis. Am. J. Obstet. Gynecol. 69, 962.

LAPAGE, S. P. (1961). Haemophilus vaginalis and its role in vaginitis. Acta path. microbiol. scand. 52, 34.

LAUGhton, N. (1951). Observations on the bacterial flora of the cervical canal in infertile women with cervical dysfunction. Proc. Soc. Study Fert. 3, 18.

Laughton, N. (1954). A study of a bacterium isolated from the human cervix. J. Path. Bact. 67, 169.

Laughton, N. (1963). Pneumonitis due to a pleuropneumonia-like organism and a corynebacterium associated with hyaline membrane disease. J. Path. Bact. 85, 413.

LEOPOLD, S. (1953). Heretofore undescribed organism isolated from genito-urinary system. U.S. arm. Forces med. J. 4, 263.

Leopold, S. (1956). Description of a bacterium. Bact. Rev. 20, 274.

McKAy, K. A. \& TruscotT, R. B. (1959). Reversion of avian pleuropneumonia-like organisms to bacteria. Ann. N.Y. Acad. Sci. 79, 465.

Minck, R. (1953). Récherches sur l'origine des organismes du type de la péripneumonie trouvées dans les organes génitaux de la femme. C. r. hebd. Séanc. Acad. Sci., Paris, 236, 250.

Pease, P. E. (1962). Evidence that Streptobacillus moniliformis is an intermediate stage between a corynebacterium and its L-form or derived PPLO. J. gen. Microbiol. $29,91$.

Pease, P. E. (1965). The antigenic structure of PPLO (Mycoplasma hominis) and related bacteria. J. gen. Microbiol. 41, 299.

Pease, P. E. \& Bisset, K. A. (1962). Effect of parasitism on Gram-positive bacteria, with reference to the origin of certain types of virus. Nature, Lond. 196, 357.

Pease, P. E. \& Laughton, N. (1962). Observations on corynebacterium and related pleuropneumonia-like organisms (PPLO). J. gen. Microbiol. $27,383$.

Redmond, D. L. \& Kotcher, E. (1963). Cultural and serological studies on Haemophilus vaginalis. J. gen. Microbiol. 33, 77.

Smith, P. F., Peoples, D. M. \& Morton, H. E. (1957). Conversion of pleuropneumonialike organisms to bacteria. Proc. Soc. exp. Biol. Med. 96, 550.

Wittler, R. G., CARy, S. G. \& Lindberg, R. B. (1956). Reversion of a pleuropneumonialike organism to a corynebacterium during tissue-culture passage. J.gen. Microbiol. 14, 763.

Zinnemann, K. \& Turner, G. C. (1962). Taxonomy of Haemophilus vaginalis. Nature, Lond. 195, 203.

Zinnemann, K. \& Turner, G. C. (1963). The taxonomic position of 'Haemophilus vaginalis' (Corynebacterium vaginale). J. Path. Bact. 85, 213. 